\title{
Microecology of Monogenean Gill Parasites of Tilapia Rendalli Boulenger, 1897 From Bamendjing Lake,
}

\section{Cameroon}

\author{
TOMBI Jeannette (Corresponding author) \\ University of Yaoundé I, Faculty of Science, Laboratory of Parasitology and Ecology, P. \\ O. BOX 812, Yaoundé, Cameroon
}

Tel. 327-675-85-43-20Ｅ-mail: tombijeannette2007@yahoo.fr

TCHIEGNO Joëlle Miriane

University of Yaoundé I, Faculty of Science, Laboratory of Parasitology and Ecology, P. O. BOX 812, Yaoundé, Cameroon

E-mail: joelletchiegno@yahoo.com

\begin{abstract}
AKOUMBA John Francis
University of Yaoundé I, Faculty of Science, Laboratory of Parasitology and Ecology, P. O. BOX 812, Yaoundé, Cameroon

E-mail: akjfjohnfrancis@yahoo.fr
\end{abstract}

Received: April 22, 2017 Accepted: May 24, 2017 Published: June 4, 2017

doi:10.5296/jee.v8i1.11133ＵRL: https://doi.org/10.5296/jee.v8i1.11133

\begin{abstract}
The present work aimed to study preferences for microhabitat by the monogenean gill parasites of Tilapia rendalli Boulenger, 1897. Fifty-four specimens were sampled using gill net in February 2014 at Bamendjing Lake. Each gill arch was removed and examined to both quantify the number of parasites and their distribution on the gills. This examination enabled us to find 6583 specimens of monogeneans belonging to 5 different species, Cichlidogyrus arthracanthus, C. dossoui, C. quaestio, C. tiberianus and C. tilapiae with 3708, 1708, 858, 210 and 99 individuals respectively. All species were aggregated within the host population.
\end{abstract}




\section{Macrothink}

Journal of Environment and Ecology

ISSN 2157-6092

2017, Vol. 8, No. 1

The spatial distribution of each parasite species was studied on different partitions of the gill arches. This study supports the hypothesis that gill site preference is a result of water flow over gills during respiration and mate finding habitat. There was no evidence of competition among the various species.

Keywords: Monogenea, Ectoparasites, Tilapia rendalli, Site preference, Bamendjing Lake 


\section{Introduction}

The role of parasitism seems essential in ecology because parasites are good tools to study the structure and the organization of communities (Mouritsen \& Poulin, 2002; Koehler \& Poulin, 2010). Monogenean gill parasites are not exceptional to this rule. These organisms constitute the most ubiquitous and abundant group of helminth parasites in the aquatic environment. More than $95 \%$ are fish ectoparasites and highly host specific when compared to other groups of parasites (Whittington et al., 2000; Matejusova et al., 2003; Ivona, 2004). Most species are restricted not only to a particular host, but also to a particular part of the host (Poulin, 2002; Turgut et al., 2006; Bi \& Janovy, 2011; Soylu et al., 2013). For these reasons, monogenean gill parasites are suitable models to study site selection (Desdevises et al., 2002). Various cases of site preference have been identified in relation to gill arch, hemibranch, sector or filamentous zone. The effect of these gill preferences is not clear and many host and environmental factors could be involved (Pie et al., 2006). Monogenean site specificity have been associated with particular feeding guilds and diet (Marcogliese, 2002), reinforcement of reproductive barriers and en-hancement of the chance to mate (Whittington \& Ernest, 2002), avoidance of intra and interspecific competition (Rohde et al., 1995), differences in the area between the gill arches (Buchmann, 1999).

Systematic studies carried out by Paperna (1960), Ergens (1981) and Douëllou (1993) revealed the presence of several monogenean species belonging to Cichlidogyrus genus on the gills of Tilapia rendalli Boulenger, 1897. In Cameroon, the ecological studies of the monogenean gill parasites of this Cichlid are nonexistent. The aim of this study is to examine some aspects of monogeneans ecology in terms of site preference within an ecological framework (i.e number and distribution of parasites).

\section{Materials and Methods}

\subsection{Host Collection}

A total of 54 adult T. rendalli were sampled in February 2014 at Bamendjing hydroelectric reservoir also called Lake Bamendjing ( $5^{\circ} 49^{\prime} 60^{\prime \prime} \mathrm{N}$ and $10^{\circ} 30^{\prime} 00^{\prime \prime} \mathrm{E}$ ). All fish were caught using a $1 \mathrm{~cm}$ by $1 \mathrm{~cm}$ mesh gillnet by local fishermen. Right away after sampling, the fish individuals were immersed into $10 \%$ formalin solution and transported to the laboratory for parasitological analysis (Tombi et al., 2014).

\subsection{Spatial Distribution of Parasite Species}

Gills from the left and right sides of the fish were dissected. Data regarding the distribution of monogeneans on the gill biotope of $T$. rendalli were carried out in special topographic card (Figure 1). The gill arches were numbered 1 to 4 from anterior to posterior. Each gill arch was divided into two hemibranches and five sectors: dorsal (S1), medio-dorsal (S2), median (S3), medio-ventral (S4) and ventral (S5). In addition, three equidistant zones: distal zone (1), median zone (2) and basal zone (3) were established at the level of each gill filament and following the vertical gradient. 


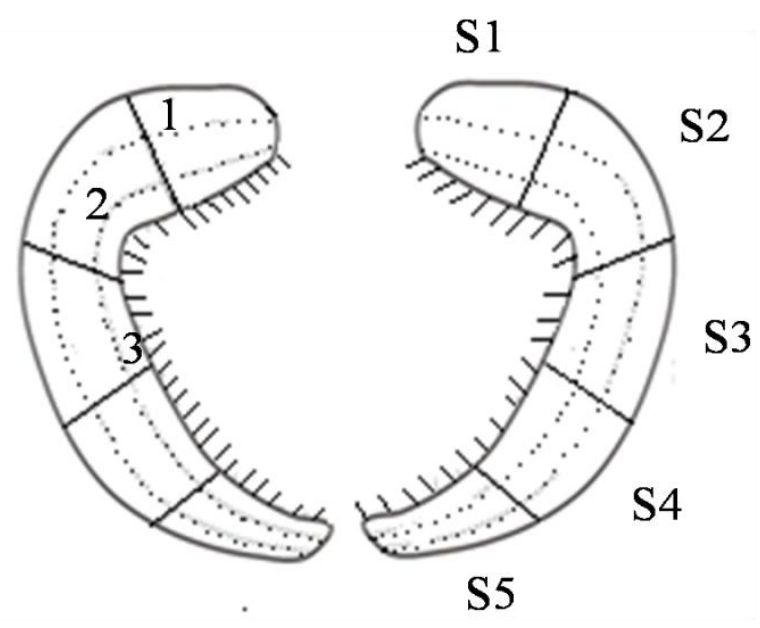

\section{Posterior hemibranch}

Anterior hemibranch

Figure 1. Schematic drawing of hemibranches showing division into sectors and zones

\subsection{Parasite Data}

Under a stereo-microscope, each hemibranch was examined filament by filament from the dorsal towards the ventral part. The position of each monogenean individual found on each gill filament was recorded in order to determine the microhabitat preference of each species. The specimen was then isolated, mounted on slide in a drop of water and observed with an OLYMPUS M50 light microscope. All species were identified using sclerotized parts of the haptor and reproductive organs according to Paperna (1960), Ergens (1981) and Douëllou (1993).

\subsection{Statistical Analysis}

Prevalence (\%) and mean intensity were use as defined by Bush et al. (1997). The distribution of each monogenean species on particular gill arches, hemibranches, sectors and zones was analyzed by Kruskal Wallis's K test and Mann-Whitney's U test to assess the significance of the difference. Differences of $\mathrm{P}<0.05$ were considered significant. Statistix version 2.0 and Microsoft Excel software were used for the analysis of various data.

\section{Results}

During this study, 54 Tilapia rendalli caught in the Bamendjing Lake were examined and all were infected. A total of 6583 specimens of monogenean were recorded on the gills of this fish host including Cichlidogyrus arthracanthus, C. dossoui, C. quaestio, C. tilapiae and C. tiberianus. All these species had the typical aggregated pattern of distribution $\left(\mathrm{S}^{2}>\mathrm{Im}\right)$.

\subsection{General Occurrence of the Parasites}

The distribution of C. arthracanthus, C. dossoui, C quaestio, C. tilapiae and C. tiberianus on the gills of Tilapia rendalli was analyzed (Table 1). The 54 fish infected with $C$. arthracanthus harbored 3708 individuals of this species. The difference was not significant 
between the number of parasites found on the right and on the left set of the gills $(\mathrm{U}, \mathrm{P}=$ $0.78>0.05)$. Gill arch II was preferred compared to the other three $(\mathrm{K}=18.02>7.81$; $\mathrm{df}=$ 3). A significant greater number of $C$. arthracanthus occurred on the anterior hemibranch than on the posterior one $(\mathrm{U}, \mathrm{P}=0.029<0.05)$. This species preferred the median sector $(\mathrm{K}=$ $45.40>9.48$; $\mathrm{df}=4)$ and its parasitic load progressively decreased from the distal zone towards the basal one with a significant difference between two consecutive zones $(\mathrm{P}<$ $0.05)$.

The 54 fish infected with $C$. dossoui harbored 1708 individuals of this species. This parasite did not show a left or right side preference $(\mathrm{U}, \mathrm{P}=0.935>0.05)$. The parasitic load of $C$. dossoui reduced significantly in the anteroposterior direction thus, parasites mostly occurred on the first gill arch $(\mathrm{K}=52.99>7.81 ; \mathrm{df}=3)$. The anterior hemibranch was more colonized than was the posterior one $(\mathrm{U}, \mathrm{P}=0.038<0.05)$. The specimens of this monogenean species mostly occurred on the third sector $(K=76.79>9.48 ; \mathrm{df}=4)$ and on the basal zone $(\mathrm{K}=24.15>5.99$; $\mathrm{df}=2)$.

Of the 54 dissected fish, 51 (94.44\%) were infected by C. quaestio and 858 specimens of this species were found. $C$. quaestio did not show preference for the left or right side of the gills of Tilapia rendalli $(\mathrm{U}, \mathrm{P}=0.79>0.05)$. Parasitic load decreased insignificantly in the anteroposterior direction $(\mathrm{K}=2.10<7.81 ; \mathrm{df}=3)$. C. quaestio showed more affinity for the anterior hemibranch $(\mathrm{U}, \mathrm{P}=0.0054<0.05)$, the third sector $(\mathrm{K}=28.43>9.48 ; \mathrm{df}=4)$ and the median zone $(\mathrm{K}=14.55>5.99 ; \mathrm{df}=2)$.

Of the 54 dissected fish, 31 (57.40\%) were infected by C. tiberianus and 210 parasites were collected. No significant difference was found between the number of the right and left gill parasites $(\mathrm{U}, \mathrm{P}=0.25>0.05)$. Parasitic load decreased significantly in an anteroposterior direction $(\mathrm{K}=10.99>7.81$; $\mathrm{df}=3)$. A greatest number of $C$. tiberianus was recorded on $\operatorname{arch} \mathrm{I}(\mathrm{K}=16.94>7.81 ; \mathrm{df}=3)$ and on the third sector $(\mathrm{K}=12.71>9.48 ; \mathrm{df}=4)$. No preference for zones $(\mathrm{K}=2.82<5.99$; $\mathrm{df}=2)$ and for hemibranches $(\mathrm{U}, \mathrm{P}=1.14>0.05)$ was observed.

Table1. General occurrence of monogenean species on the gills of Tilapia rendalli

\begin{tabular}{|c|c|c|c|c|c|}
\hline Species & C. arthracanthus & C. dossoui & C. quaestio & C. tiberianus & C. tilapiae \\
\hline $\mathrm{M}(\mathrm{SD})$ & $68.67(47.97)$ & $31.63(18.47)$ & $16.82(20.07)$ & $6.77(7.02)$ & $2.91(1.82)$ \\
\hline Left side & 1897 & 878 & 399 & 87 & 60 \\
\hline Right side & 1811 & 830 & 459 & 123 & 39 \\
\hline Gill arch I & 1059 & 636 & 263 & 75 & 25 \\
\hline
\end{tabular}




\begin{tabular}{|c|c|c|c|c|c|}
\hline Gill arch II & 1132 & 470 & 232 & 64 & 40 \\
\hline Gill arch III & 964 & 415 & 211 & 47 & 17 \\
\hline Gill arch IV & 553 & 187 & 152 & 24 & 17 \\
\hline \multirow{2}{*}{$\begin{array}{c}\text { Anterior } \\
\text { hemibranch }\end{array}$} & 1954 & 1098 & 475 & 88 & 46 \\
\hline & & & & & \\
\hline \multirow{2}{*}{$\begin{array}{c}\text { Posterior } \\
\text { hemibranch }\end{array}$} & 1754 & 610 & 383 & 122 & 53 \\
\hline & & & & & \\
\hline Sector 1 & 422 & 169 & 39 & 14 & 15 \\
\hline Sector 2 & 930 & 354 & 179 & 65 & 33 \\
\hline Sector 3 & 1095 & 571 & 326 & 75 & 19 \\
\hline Sector 4 & 948 & 451 & 268 & 42 & 25 \\
\hline Sector 5 & 313 & 163 & 46 & 14 & 7 \\
\hline Distal zone & 2131 & 33 & 228 & 56 & 74 \\
\hline$\overline{\text { Median zone }}$ & 1477 & 112 & 589 & 58 & 12 \\
\hline Basal zone & 100 & 1563 & 41 & 96 & 13 \\
\hline
\end{tabular}

Of the 54 examined fish, $34(62.96 \%)$ were infected with C. tilapiae. A total of 99 individuals were recorded and no preference for gill arches $(K=6.96<7.81$; $\mathrm{df}=3)$, hemibranches $(\mathrm{U}$, $\mathrm{P}=1.26>0.05)$, sectors $(\mathrm{K}=6.06<9.48 ; \mathrm{df}=4)$ and zones $(\mathrm{K}=3.49<5.99 ; \mathrm{df}=2)$ was observed.

\subsection{Simultaneous Occurrence of all the Parasite Species (Table 2)}

Twenty-two $T$. rendalli were simultaneously parasitized with the five monogenean species. In these hosts, 1741 C. arthracanthus, 796 C. dossoui, 542 C. quaestio, 71 C. tilapiae and 141 C. tiberianus were recorded. The number of the specimens of each species was similar on both sides of the host (U, P> 0.05). C. arthracanthus preferred gill arches I, II and III (K=9.02 > 7. 81 ; $\mathrm{df}=3)$, median sector $(\mathrm{K}=24.46>9.48$; $\mathrm{df}=4)$ and distal zone $(\mathrm{K}=82.34>5.99$; $\mathrm{df}$ =2). A significantly greater number of $C$. dossoui occurred on gill arch $\mathrm{I}(\mathrm{K}=29.43>7.81$; $\mathrm{df}$ $=3)$, anterior hemibranch $(\mathrm{U}, \mathrm{P}=0.000<0.05)$, median sector $(\mathrm{K}=45.47>9.48 ; \mathrm{df}=4)$ and basal zone $(\mathrm{K}=63.5>5.99$; $\mathrm{df}=2)$. C. quaestio preferred median sector $(\mathrm{K}=38.43>9.48$; $\mathrm{df}=4)$ and median zone $(\mathrm{K}=19.66>5.99$; $\mathrm{df}=2)$. C. tiberianus preferred posterior hemibranch $(\mathrm{U}, \mathrm{P}=0.034<0.05)$ and median sector $(\mathrm{K}=30.39>9.48$; $\mathrm{df}=4)$. C. tilapiae preferred gill arch II $(\mathrm{K}=11.52>7.81 ; \mathrm{df}=3)$ and distal zone $(\mathrm{K}=12.65>5.99 ; \mathrm{df}=2)$.

Table 2. Distribution of monogenean species on the gills of Tilapia rendalli in simultaneous infection

\begin{tabular}{|c|c|c|c|c|c|}
\hline Species & C. arthracanthus & C. dossoui & C. quaestio & C. tiberianus & C. tilapiae \\
\hline $\mathrm{M}(\mathrm{SD})$ & $79.14(49.74)$ & $36.18(16.88)$ & $24.18(27.58)$ & $6.41(6.35)$ & $3.23(1.82)$ \\
\hline Left side & 913 & 426 & 254 & 52 & 44 \\
\hline Right side & 838 & 370 & 288 & 89 & 27 \\
\hline Gill $\operatorname{arch} I$ & 514 & 296 & 167 & 48 & 20 \\
\hline
\end{tabular}




\begin{tabular}{|c|c|c|c|c|c|}
\hline Gill arch II & 523 & 219 & 145 & 39 & 26 \\
\hline Gill arch III & 462 & 191 & 133 & 36 & 12 \\
\hline Gill arch IV & 242 & 90 & 97 & 18 & 13 \\
\hline \multirow{2}{*}{$\begin{array}{c}\text { Anterior } \\
\text { hemibranch }\end{array}$} & 917 & 516 & 336 & 54 & 38 \\
\hline & & & & & \\
\hline \multirow{2}{*}{$\begin{array}{c}\text { Posterior } \\
\text { hemibranch }\end{array}$} & 824 & 280 & 206 & 87 & 33 \\
\hline & & & & & \\
\hline Sector 1 & 171 & 64 & 16 & 4 & 11 \\
\hline Sector 2 & 422 & 144 & 104 & 47 & 22 \\
\hline Sector 3 & 635 & 293 & 207 & 56 & 15 \\
\hline Sector 4 & 406 & 215 & 184 & 27 & 16 \\
\hline Sector 5 & 107 & 80 & 31 & 7 & 7 \\
\hline Distal zone & 999 & 700 & 56 & 63 & 15 \\
\hline$\overline{\text { Median zone }}$ & 668 & 66 & 353 & 40 & 16 \\
\hline Basal zone & 74 & 30 & 133 & 38 & 40 \\
\hline
\end{tabular}

\subsection{Simultaneous Occurrence of the Abundant Parasites Species (Table 3)}

This type of infection concerned $C$. arthracanthus, $C$. dossoui and $C$. quaestio. Each of this trio infected more than $90 \%$ of hosts dissected. Of the 54 fish examined, 11 (20.37\%) were simultaneously parasitized by this trio and harbored 620 C. arthracanthus, 271 C. dossoui and 79 C. quaestio. $C$. arthracanthus preferred distal zone $(\mathrm{K}=10.98>5.99 ; \mathrm{df}=2)$. $C$. dossoui preferred gill arch $\mathrm{I}(\mathrm{K}=8.05>7.81$; $\mathrm{df}=3)$, anterior hemibranch $(\mathrm{U}, \mathrm{P}=0.01<$ $0.05)$ and basal zone $(\mathrm{K}=13.98>5.99 ; \mathrm{df}=2)$. C. quaestio showed no preference for gill arches $(\mathrm{K}=0.55<7.81 ; \mathrm{df}=3)$, hemibranches $(\mathrm{U}, \mathrm{P}=0.84>0.05)$, sectors $(\mathrm{K}=6.32<9.48$; $\mathrm{df}=4)$ and zones $(\mathrm{K}=0.81<5.99 ; \mathrm{df}=2)$.

Table 3. Distribution of monogenean in simultaneous occurrence of the abundant species

\begin{tabular}{|c|c|c|c|}
\hline Species & C. arthracanthus & C. dossoui & C. quaestio \\
\hline $\mathrm{M}(\mathrm{SD})$ & $56.36(53.28)$ & $24.67(18.41)$ & $7.5(6.06)$ \\
\hline Left side & 322 & 130 & 38 \\
\hline Right side & 298 & 141 & 41 \\
\hline Gill arch I & 155 & 107 & 21 \\
\hline Gill arch II & 197 & 62 & 22 \\
\hline Gill arch III & 167 & 66 & 22 \\
\hline Gill arch IV & 101 & 36 & 14 \\
\hline \multirow{2}{*}{$\begin{array}{c}\text { Anterior } \\
\text { hemibranch }\end{array}$} & 287 & 176 & 45 \\
\hline & & & \\
\hline \multirow{2}{*}{$\begin{array}{c}\text { Posterior } \\
\text { hemibranch }\end{array}$} & 333 & 95 & 34 \\
\hline & & & \\
\hline Sector 1 & 63 & 33 & 4 \\
\hline Sector 2 & 136 & 58 & 13 \\
\hline Sector 3 & 191 & 93 & 33 \\
\hline Sector 4 & 172 & 57 & 26 \\
\hline
\end{tabular}




\begin{tabular}{|c|c|c|c|}
\hline Sector 5 & 58 & 30 & 3 \\
\hline Distal zone & 360 & 9 & 23 \\
\hline$\overline{\text { Median zone }}$ & 225 & 14 & 51 \\
\hline Basal zone & 35 & 248 & 5 \\
\hline
\end{tabular}

\section{Discussion}

The present study reports occurrences of five monogenean species parasitizing the gills of Tilapia rendalli from Bamendjing Lake. In Cameroon, simultaneous colonization of Cichlid gill systems by several monogenean species has already been reported (Dossou \& Birgi, 1984; Tombi et al., 2014). Such observations were also made for other African Cichlids (Pariselle et al., 2003; Ibrahim, 2012). The coexistence of congeneric species in the gill system of $T$. rendalli allows the exclusion of interspecific competition among the factors involved in the structuring of this component community. According to Lim (1990), competition does not permit similar species to coexist. For Rohde (1994), positive interactions are more frequent between fish ectoparasites of the same host than negative interactions. Niche heterogeneity, unpredictable recruitment or the aggregated utilization of fragmented resources favour species coexistence (Morand et al., 1999).

All the parasite species presented an aggregate distribution which is in accordance with the typical distribution pattern found in fish parasites and can be explained by the heterogeneity of the host-parasite relationship (Nering \& Zuben, 2010). This observation fits the conclusion of Langlais \& Silan (1995) indicating that in intensive fish farming where the density of hosts is high, most of the parasite species are overdispersed.

The exploitation of both sides of the gill system of $T$. rendalli by all parasite species did not show a significant difference. Many parasitologists agreed upon this observation in Cichlid species. Tombi et al. (2014) noted an equipartition of Cichlidogyrus halli, $C$. thurstonae, $C$. tilapiae and Scutogyrus longicornis on both sides of Oreochromis niloticus. Other previous studies also didn't indicated significant preference between the left and the right sides by monogenean ectoparasites (Soylu et al., 2010; Le Roux et al., 2011; Soylu et al., 2013; Stavrescu-Bedivan, 2013; Sujana, 2015). The bilateral symmetry of T. rendalli associated to that of its monogeneans could justify a similar exploitation of both sides of this fish species (Tombi et al., 2014). This symmetry was due to the equal chances for infection of both sides with the monogenean eggs (Stavrescu-Bedivan, 2013).

This work has indicated defined microhabitat of each monogenean species. C. arthracanthus preferred gill arch II, anterior hemibranch, median sector and distal zone. C. dossoui preferred gill arch I, anterior hemibranch, median sector and basal zone. C. quaestio showed more affinity for anterior hemibranch and median sector, as well as the median zone. $C$. tiberianus preferred gill arch I, median sector and median zone. C. tilapiae preferred gill arch II and the distal zone. Various works also showed that microhabitat selection is common among fish gill monogeneans and that the choice of attachment site varies with the species (El Hafidi et al., 1998; Tombi et al., 2010; Le Roux et al., 2011; Sujana, 2015). The majority of the representatives of the studied component community are preferentially found on gill arches I and II and on the anterior hemibranch. The high water flow that passes through these 
parts of the gill system, favours the creation of suitable conditions for these monogenean species (Izumova \& Zharikova, 1982). Suydam (1971) demonstrated that the high number of Diclidophora maccallumi on the first three arches was linked to the high volume of water passing through them. All monogenean species of $T$. rendalli preferred the median sector. Similar results were obtained by Sujana (2015). Some monogeneans often prefer this sector because it is the most exposed to the respiratory current (Yang et al., 2006).

It is essentially on the vertical gradient of distribution (zonal) that occur the segregation of monogenean gill parasites of $T$. rendalli. The most abundant monogenean species, $C$. arthracanthus and $C$. dossoui preferred respectively the distal and basal zones. The second most abundant species, $C$. quaestio preferred the median zone. These three species were the main contributors to the microhabitat distribution. The least abundant species, $C$. tiberianus and $C$. tilapiae did not show a preference for zone but $C$. tilapiae had the tendency to settle on the distal zone. It is therefore clear that, to coexist the species of this guild have adopted to share their space resource. Such aggregation of individuals of each parasite species on specific zone suggests the absence of an intraspecific competition (Soylu et al., 2013). For Rohde (1977), this restriction of the niche facilitates mating. However, according to Buchmann \& Lindenstrom (2002), the exact explanation of site selection by the monogeneans remains enigmatic. Despite sharing the space resource by the five species studied, there is some mutual tolerance between them as their respective niches tend to overlap indicating the absence of interspecific competition.

\section{References}

Bi, M., \& Janovy, J. Jr. (2011). Spatial and temporal patterns of intraspecific morphological variation in Dactylogyrus simplexus from fathead minnows in Nebraska. Journal of Parasitology, 97(6), 1003-1006. http://doi.org/10. 1645GE-2526-1.

Buchmann, K. (1999). Immune mechanisms in fish skin against monogeneans - a model. Folia Parasitologica, 46, 1-9.

Buchmann, K., \& Lindenstrom, T. (2002). Interactions between monogenean parasistes and their fish hosts. International Journal for Parasitology, 32, 309-319. http://doi.org/10.1016/S0020-7519 (01)00332-0.

Bush, A. O., Lafferty, K. K., Lotz, J. M., \& Shostak, A. W. (1997). Parasitology meets ecology on its own terms: Margolis et al. revisited. Journal of Parasitology, 83, 575-583. http://doi.org/10. 1645/13-326.1.

Desdevises, Y., Morand, S., Jousson, O., \& Legendre, P. (2002). Coevolution between Lamellodiscus (Monogenea: Diplectanidae) and Sparidae (Teleostei): the study of a complex host-parasite system. Evolution, 56, 2459-2471.

Dossou, C., \& Birgi, E. (1984). Monogènes parasites d'Hemichromis fasciatus Peters, 1857 (Teleostei, Cichlidae). Annales des Sciences naturelles, Zoologie, 6, 101-109. http://doi.org/10.10 16/S0003-4339.

Douëllou, L. (1993). Monogeneans of the genus Cichlidogyrus Paperna, 1960 
(Dactylogyridae: Ancyrocephalinae) from Cichlid fishes of Lake Kariba (Zimbabwe) with descriptions of five new species. Systematic Parasitology, 25, 159-186. http://doi.org/10. 10007/BF00007007.

El Hafidi, F., Berrada-Rkhami, O., Benazzou, T., \& Gabrion, C. (1998). Microhabitat distribution and coexistence of Microcotylidae (Monogenea) on the gills of the striped mullet Mugil cephalus: chance or competition? Parasitology research, 84, 315-320.

Ergens, R. (1981). Nine species of the genus Cichlidogyrus Paperna, 1960 (Monogenea: Ancyrocephalinae) from Egyptian fishes. Folia Parasitologica, 28, 205-214.

Ibrahim, M. M. (2012). Variation in parasite infracommunies of Tilapia zillii in relation to some biotic and abiotic factors. International Journal of Zoological Research, 8(2), 59-70. http://doi.org/10. 3923/ijzr.2012.59.70.

Ivona, M. (2004). Monogenean parasites in Adriatic cage-reared fish. Acta Adriatica, 5, $65-73$.

Izumova, N. A., \& Zharicova, T. I. (1982). About some peculiarities of distribution of Dactylogirus ancharatus and D. chranilowi (Monogenoidea (Beneden) Bychowsky, 1937; Dactylogiridea Bychowsky, 1937) on gills of carps of the Volga basin reservoirs. Leningrad: Nauka (pp 89-100). Russian.

Koehler, A. V., \& Poulin, R. (2010). Host partitioning by parasites in an intertidal crustacean community. Journal of Parasitology, 96(5), 862-868. http://doi.org/10. 1645/GE-2460.1.

Langlais, M., \& Silan, P. (1995). Theoretical and mathematical approach of some regulation mechanisms in a marine host-parasite system. Journal of Biological Systems, 3(2), 559-568. http://doi.org/10 11.42/S0218339095000514.

Le Roux, L. E., Avenant-Oldewage, A., \& Van Der Walt, F. C. (2011). Aspects of the ecology of Cichlidogyrus philander collected from Pseudocrenilabrus philander philander from the Padda Dam, Gauteng, South Africa. African Zoology, 46(1), 103-116. http://doi.org/10. 3377/004.046.0102.

Lim, L. H. S. (1990). Freshwater monogeneans of Peninsular Malaysia. Asian Fisheries Science, 3, 275-285.

Marcogliese, D. J. (2002). Food webs and the transmission of parasites to marine fish. Parasitology, 124: S83- S99.

Matejusova, I., Simkova, A., Sasal, P., \& Gelnar, M. (2003). Microhabitat distribution of Pseudodactylogyrus anguillae and Pseudodactylogyrus bini among and within gill arches of the European eel (Anguilla anguilla L.). Parasitology Research, 89, 290-296.

Morand, S., Poulin, R., Rohde, K., \& Hayward, C. (1999). Aggregation and species coexistence of ectoparasites of marine fishes. International Journal for Parasitology, 29, 663-672. http://doi.org/10. 1016/S0020-7519(99)00029-6.

Mouritsen, K. N., \& Poulin, R. (2002). Parasitism, community structure and biodiversity in 
intertidal ecosystem. Parasitotogy, 124, 101-117. http://doi.org/10. 1017/S00311820 02001476 .

Nering, M. B., \& Zuben, C. J. V. (2010). Métodos Quantitativos em Parasitologia. Jaboticabal: Funep.

Paperna, I. (1960). Studies on Monogenetic Trematodes in Israel. 2 Monogenetic Trematodes of Cichlids. Bamidgeh, Bulletin of Fish Culture in Israel, 12, 20-33.

Pariselle, A., Bilong Bilong, C. F., \& Euzet, L. (2003). Four news species of Cichlidogyrus Paperna, 1960 (Monogenea: Ancyrocephalidea), all gill parasites for African mouthbreeder tilapias of the genera Sarotherodon and Oreochromis (Pisces, Cichlidae), with a redescription of Cichlidogyrus thurstonae Ergens, 1981. Systematic Parasitology, 56, 201-210. http://doi.org/10. 1023/B:SYPA.0000003807.27452.bd.

Pie, M. R., Enger, K. B., \& Boeger, W. A. (2006). Density-dependent topographical specialization in Gyrodactylus anisopharynx (Monogenoidea, Gyrodactylidae): boosting transmission or evading competition? Journal of Parasitology, 90, 459-463.

Poulin, R. (2002). The evolution of monogenean diversity. International Journal for Parasitology, 32, 245-254.

Rohde, K. (1994). Niche restriction in parasites: proximate and ultimate cause. Parasitology, 109, 69-84.

Rohde, K. (1977). A non competitive mechanism responsible for restricting niches. Zoologischer Enzeiger, 199(3/4), 164-172.

Soylu, E., Çolak, S. Ö., Erdogan, F., Erdogan, M., \& Tektas, N. (2013). Microhabitat distribution of Pseudodactylogyrus anguillae (Monogenea), Ergasilus gibbus and Ergasilus lizae (Copepoda) on the Gills of European Eels (Anguilla anguilla, L.). Acta zoologyca Bulgaria, 65(2), 251-257. http://doi.org/10. 3906/ZOO-0808-14.

Soylu, E., Rüzgar, B., \& Soylu, M. (2010). Seasonal dynamics and spatial distribution of Dactylogyrus crucifer Wagener, 1857 on the gills of roach (Rutilus rutilus L.) from Lake Sapanca, Turkey. Turkish Journal of Zoology, 34, 393-398.

Stavrescu-Bedivan, M. M. (2013). Some aspects of branchial parasitism in Rutilus rutilus (Linnaeus, 1758) from Moara Domnească Lake. Romanian Journal of Bioliology- Zoology, 58(2), 93-99.

Sujana, M. (2015). Microhabitat distribution of metazoan parasites on the gills of L. rohita. Online International Interdisciplinary Research Journal, 5(1), 140-154.

Suydam, E. L. (1971). The micro-ecology of three species of monogenetic trematode of fishes from the Beaufort Cape Haheras area. Proceeding of the Helminthological Society of Washington, 38, 240 - 246.

Tombi, J., Akumba, J. F., \& Bilong Bilong, C. F. (2014). The monogenean community on the gill of Oreochromis niloticus from Mélen fish station in Yaoundé, Cameroon. International 
Journal of Modern Biological Research, 2, 12-23.

Tombi, J., Nack, J., \& Bilong Bilong, C. F. (2010). Spatial distribution of monogenean and myxosporidian gill parasites of Barbus martorelli Roman, 1971 (Teleostei: Cyprinid): The role of intrinsic factors. African Journal of Agricultural Research, 5(13), 1662-1669. http://doi.org/10. 5897/AJAR09.093.

Turgut, E., Shinn, A., \& Wotten, R. (2006). Spatial distribution of Dactylogyrus (Monogenean) [sic] on the gills of the host fish. Turkish Journal of Fisheries and Aquatic Sciences, 6, 93-98.

Whittington, I. D., \& Ernest, I. (2002). Migration, site-specificity and development of Benedenia lutjani (Monogenea: Capsalidae) on the surface of its host, Lutjanus carponotatus (Pisces: Lutjanidae). Parasitology, 124, 423-434.

Whittington, I. D., Cribb, B. W., Hamwood, T. E., \& Halliday, J. A. (2000). Host-specificity of monogenean (Platyhelminth) parasites: a role for anterior adhesive areas? International Journal for Parasitology, 30, 305-320.

Yang, T., Liu, J., Gibson, D. I., \& Dang, A. (2006). Spatial distribution of two species of monogeneans on the gills of Siganus fuscescens (Houttuyn) and their seasonal dynamics in caged versus wild-caugth hosts. Journal of Parasitology, 92, 933-940.

\section{Copyrights}

Copyright for this article is retained by the author(s), with first publication rights granted to the journal.

This is an open-access article distributed under the terms and conditions of the Creative Commons Attribution license (http://creativecommons.org/licenses/by/4.0/) 